\title{
Lecturers' Job Effectiveness Tertiary Institutions Benefits in Cross River State, Nigeria
}

\author{
Franca Udey
}

\begin{tabular}{l} 
ARTICLE INFO \\
\hline Article History: \\
Received 10.11 .2019 \\
Received in revised form \\
06.05 .2020 \\
Accepted \\
Available online 01.07 .2020
\end{tabular}

\section{INTRODUCTION}

Emolument/fringe benefits are reward used for motivation of staff in an organization in other to enhance their job effectiveness (Udey, 2010). An organizations' reward system consists its formal (Emolument) and informal (fringe benefits) mechanisms for defining the kinds of behaviour desired, evaluating performance, and rewarding good performance. Emolument is the former money or payment for work you have done, that is payment attached to an office. It is usually based on an officially specified salary for each academic rank in higher institutions. It includes a fixed schedule of salary step e.g. a university staffs' salary and for collages of education.

In a study conducted by Ndagi (2006), the problem of retention of secondary school teachers, the economic disadvantage and poor monetary benefits were identified as factors militating against teachers' satisfaction in secondary schools. Fringe benefit is defined by Peretomode(2001) as extra income entitlement given especially to an employee by management in addition to salary or wages. It can also be referred to as "Supplementary compensation practice". He added that fringe benefits programmes are now major components and constitute a substantial portion of the total labour cost of most organizations.

This gives credence to Casio (1992) that compensation systems should have a relationship to the developmental stage of the organization. Oswald, (2006), researched on compensation system attitude to work and job effectiveness of secondary school teachers in Cross River State. He states seven hypotheses to guide the study. Two set of instrument on teachers' compensation system questionnaire (TCSQ) and student assessment of teacher attitude to work and job effectiveness questionnaire (SATAWJEQ) were developed, validated and ministered to five (500) hundred teachers and two thousand students who assessed the teachers, respectively. The sample was drawn using stratified random sampling method, from thirty (30)

basseymoses2@yahoo.com, Department of Educational Management, Cross River University of Technology, Calabar, orcid.org/00000001-5325-4598 
secondary schools in the three educational zones of Cross River State. The data obtained was analyzed using Pearson product moment correlation co-efficient ( $\mathrm{r}$ ) and multiple regression analysis statistics at 0.05 level of significances. The major findings of the study showed that, there was no significant relationship between compensation variables with attitude to work and job effectiveness when taken together. But when taken individually salary, gratuity/pension (monetary compensation), and development (non-monetary compensation) had significant relationship with attitude to work and job effectiveness of teachers. The implication is that workers should be paid adequate salaries, compensation and fringe benefits should be paid promptly to enhance their job effectiveness and integrity at work.

In support of this study, Udey (2002) in her research work on reward systems and teachers' attitude to work indicated that rewards which are valued and clearly linked to desire behaviours are rewards that are equitable to their job. This can promote positive attitude to work, thereby promoting job effectiveness' of both the staff and the organization. Edem (1987) encouraged school principal to co-operate with ministry and boards of education to provide incentive to teachers if high moral and instructional effectiveness are to be maintained. In the same vein, Ejiogu (1985) in his study discovered that cash bonuses served as the best stimulant that encourage high productivity among building construction artisans, especially when such were made contingent upon performance.

Frase and piland (1989) also noted the consistence failure of schemes to reform education in America schools through the use of financial incentives to attract and retain better teachers and motivate teachers to improve, they have claimed that such schemes failed because teachers are not motivated by money, and have expressed doubts about the likelihood of them achieving greater success in higher education settings. In contrast, extrinsic rewards have, in fact been effective motivators for academics: the substantially increased rewards available for research since the second world war have clearly had a resounding effect on faculty (lecturers) behaviour.

Adeyemi (1991) observed that remuneration is the price of labour. He claimed further that, remuneration measure the work rate of the workers and rewards them in accordance to their success in meeting organizational targets. A worker is worthy of his benefits. Okpabi (1990) in his study on factors that influence teachers' effectiveness in secondary school in Gokana Tai Eleme Local Government Area of River State observed that teachers need money to meet their insatiable needs. Based on this, concluded that teachers' financial benefits should be paid regularly, as this increase their job effectiveness. Ejiogu (1980) used teachers as subjects in a study of the effects of fringe benefits of employee. In his findings, all subjects expressed grave dissatisfaction with the fringe benefits provided by the employers. He concluded that teachers were interested to move into more lucrative jobs than teaching. The implication is that when fringe benefits are not commensurate with the job, teachers will be ineffective.

Fabiyi (2000) establish the relationship between conditions of service and teacher productivity, teaching effectiveness analysis report in his findings that condition of service, fringe benefits such as salary package, staff development scheme and office accommodation accounted for 22 percent of the total variance in teaching effectiveness. An analysis of variance produced an F-ratio of 2, 46989, significant at 0.05 alpha levels. Also to determine the relationship of each of the condition of service variables such as salary, promotion, recognition of teaching, welfare package, staff development scheme and office accommodation to teachers' productivity. The results showed that all the condition of service/fringe benefits, the basic remuneration or salary was the crucial predictor of productivity. This is evident that adequate salary would promote job effectiveness.

Sulton and Bergerson (2001) in their research on faculty compensation systems: impact on the quality of higher education stated that, as institutional policy - makers develop on agenda for the new decade, faculty compensation should be viewed as a critical management tool for increasing faculty productivity, improving 
cost efficiency and enhancing their institutions (Osaba 2006; Lillydahl and Sungell, 1993). A hypothetical faculty of compensation funding feedback model with characteristics of an ideal faculty. Identified the following compensation system as follows:

1. The value, vision, mission and goals of the organization must be clearly specifically defined so that the objectives are clear to all the participants.

2. Each individual in some ways must accept personal responsibility for achieving the goals and accomplishing the mission of the organization.

3. Faculty performing at a satisfactory level must receive a compensation increase to maintain constant standard of living, while faculty performing at an above satisfactory level should receive a compensation increase appropriately more than the satisfactory level.

4. Faculty must believe the compensation to be administered in fair and objective manners.

They belief that the establishment of an appropriate compensation for job effectiveness when maintained in higher education will have a major impact on the future success and quality of the institutions, Heller and Hindle (1998) belief that, for reward to motivate, make sure you encourage compensation among staff by acknowledging individual achievement and giving appropriate recognition to high-fliers.

\section{Statement of the problem}

The role of tertiary institutions in economic, social and political development of the nation cannot be over emphasized. This is because nations all over the world depend on ideas, knowledge and sound academic research for societal development. However, the accomplishment of objectives of any higher institution depends largely on the effectiveness of its staff. For effectiveness and high turnover in higher institution to be achieved issues of motivation and workers' wellness must be given priority. The role of lecturers in tertiary institutions is central to the actualization of higher educational objectives. This why lecturers are often held accountable when things go wrong within the system. However, the problem that necessitated the present study is the issue of ineffectiveness on the part of lecturers as regards their job performance. For some time now, the nature of lecturers' performance has generated a lot of public concern. These concerns are current issues in tertiary institutions which include lateness to class, absenteeism, sexual abuse, extortion, examination malpractice, absconding from duties and unethical practices have been highly prevalent among lecturers in higher institutions of learning. Although tertiary institution management have put in efforts through its various control measures, these efforts seemed not to be yielding enough success, as things continue to get out of hands. Thus, this study sought to investigate institutional emolument/fringe benefits and job effectiveness of lecturers in public tertiary institutionsin Cross River State, Nigeria.

\section{Methodology}

The study was aimed at examining the relationship between institutional emolument/fringe benefits and job effectiveness of lecturers in public tertiary institutions in Cross River State, Nigeria. The ex-post facto research design was adopted for the study. One hypothesis was formulated and tested using Pearson Product Moment Correlation Coefficient at 0.05 level of significance. The population of this study was 1744 lecturers from four public institutions in Cross River State (University of Calabar, Cross River University of Technology, Federal College of Education Obudu and Cross River State College of Education, Akamkpa). The sample was arrived at using the stratified random sampling technique. The sample was stratified into age, gender, ethnicity and school. The sample size of the study stood at 610 lecturers, which represents 35\% of the population. 1830 students from the four institutions were purposively selected to respond to items that measures lecturers' job effectiveness. 
The questionnaire formed the major instruments used for data collection for the study. The questionnaires were designed and administered by the researcher. The questionnaires were of two categories; "Lecturers' Opinion on Institutional emolument/fringe benefits and their job effectiveness (LOIEFBJE)" and "Student Opinion Questionnaire" (SOQ) were used for data collection. The two instruments were given to experts in measurement and evaluation for vetting and validation before the administration of the instruments. To ensure the reliability of the instruments, a split half method of reliability was adopted. The reliability produced the value of 0.75 for the LOIEFBJEand 0.83 for the SOQ respectively. These values indicate a high reliability of the instrument.

\section{Findings:}

This hypothesis state that lecturers' satisfaction with institutional emolument and fringe benefits does not significantly relate to their job effectiveness. To test this hypothesis, the Pearson Product Moment Correlation was done. The result of the analysis is display in Table below.

Table 1: Pearson product moment correlation coefficient (r) analysis of relationship between lecturers' satisfaction with institutional emoluments/fringe benefits and their job effectiveness $(n=610)$.

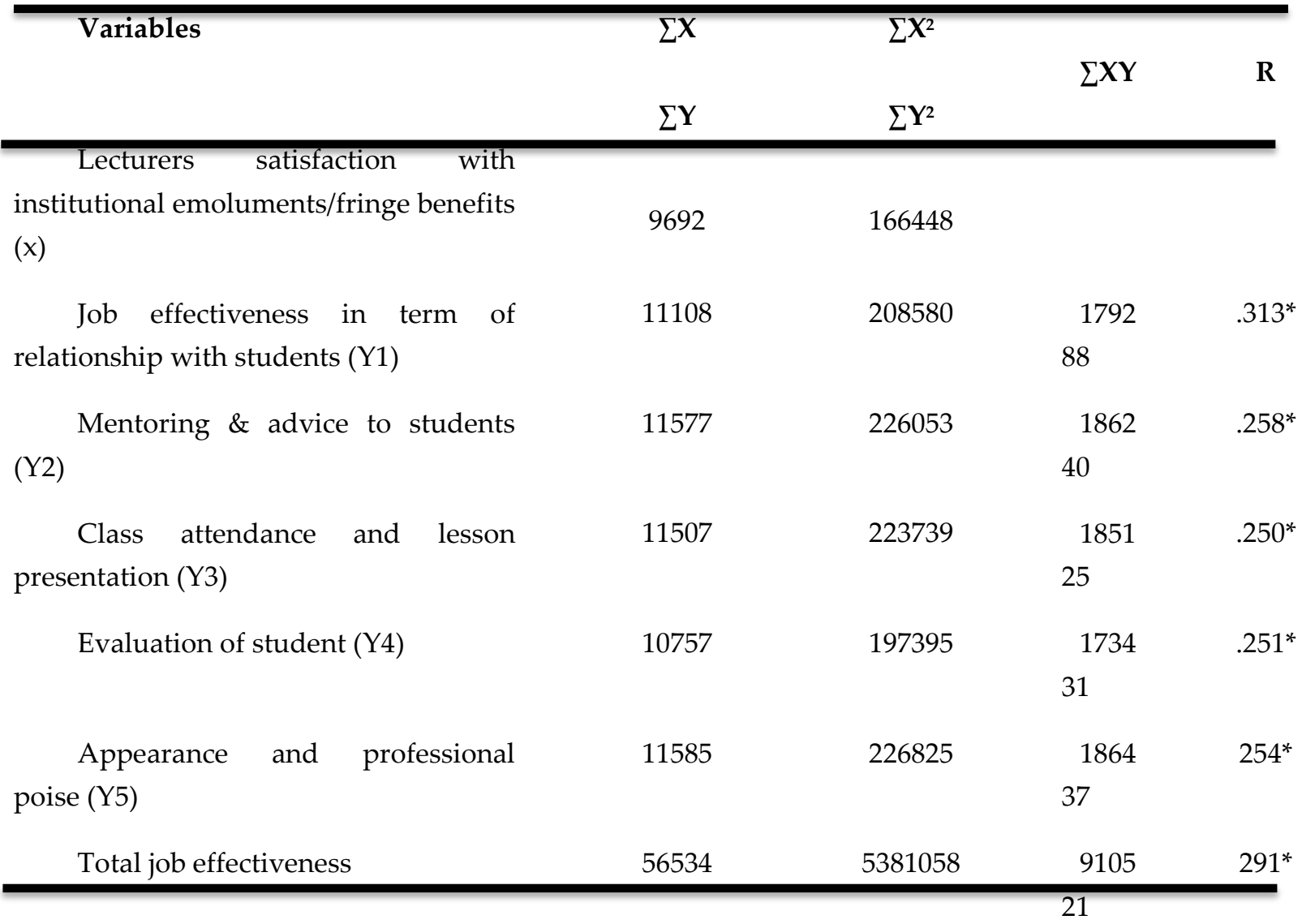

${ }^{*}$ Significant at $.05 ; \mathrm{df}=608 ;$ critical $\mathrm{r}-$ value $=.080$

The positive relationship observed in the result implies that, the higher the lecturers' satisfaction with institutional emoluments and fringe benefits, the higher their job effectiveness in terms of relationship with students; mentoring/advice to students; class attendance/lesion presentation; evaluation of students, personal appearance and professional poise.On the other hand, the lower lecturers' satisfaction with institutional emoluments and fringe benefits, the lower their job effectiveness in terms of relationship with students; mentoring/advice to students; class attendance/lesion presentation; evaluation of students, personal appearance and professional poise. 


\section{RESULT, DISCUSSION, AND SUGGESTIONS}

The result presented in the table above showed that, they are a significant positive relationship between lecturers' satisfaction with institutional emolument and fringe benefits and their job effectiveness in terms of relationship with students; $(\mathrm{r}=.313$; $\mathrm{P}<.05)$; monitoring/device to students $(\mathrm{r}=.258$; $\mathrm{P}<.05)$; class attendance/lesson presentation $(r=.250 ; \mathrm{P}<.05)$; evaluation of students $(r=.251 ; \mathrm{P}<.05)$; appearance and professional poise $(\mathrm{r}=.254 ; \mathrm{P}<.05)$ and total job effectiveness $(\mathrm{r}=.291 ; \mathrm{P}<.05)$. The null hypothesis was unaccepted because the calculated r-value of .313; 258; 250;251;254 and 291 were found to be greater than critical r-value of 080 given .05 alpha level and with 608 degree of freedom. This finding means that lecturers' satisfaction with institutional emoluments and fringe benefits significantly influence their job effectiveness.

The findings revealed that lecturers' satisfaction with institutional provisions for emolument/fringe benefits significantly influenced their job effectiveness. The positive relationship observed implies that, the higher the lecturers' satisfaction with institutional provision for emolument/fringe benefits, the higher their job effectiveness in terms of relationship with students counseling/advice, class attendance/lesson presentation, evaluation of students, personal appearance and professional poise. Oswald (2006) study disagrees with this finding in the sense that, her result revealed a no significant relationship between compensation variables (salary) with teachers' attitude to work and their job effectiveness.

Other studies are in consonant with findings of institutional provision of emolument and fringe benefits in relation to job effectiveness of any organization especially when they are linked to desired behaviours (job effectiveness) and are equitable to their job output. Most studies showed that emolument and fringe benefit is the crucial predictor of productivity (Sutton and Bergerson, 2001; Okpabi, 2003; Peretomode, 2001; Adeyemi, 1991 and Olakunri, 2001). Available data showed a significant relationship between provision of emolument, fringe benefit and job effectiveness. These forms of reward can be used in higher institutions to attract and retain staff. Fringe benefits in higher institutions can be in form of research grant, transport allowance, examination supervision/teaching practice allowance, journal hazard, meal subsidy and rent allowance etc. when these benefits are not adequate and commensurate or compared to their colleague elsewhere, there is bound to be dissatisfaction, which will affect their job effectiveness.

\section{Conclusion}

Based on the study finding, the study concludes that emolument and fringe benefits significantly relates to lecturers' job effectiveness. That, when lecturers are rewarded or motivated sufficiently especially in terms of staff development, emolument, fringe benefit, professional growth and promotion, it would enhance their job effectiveness in terms of relationship with students, mentoring/advice, class attendance, lecture delivery, student evaluation, personal appearance and professional poise.

From the various studies whose findings are relevant to this topic, there is a connection between the provision of emolument and fringe benefits in relation to lecturers' job effectiveness in tertiary institutions of learning. Some of these studies revealed that emolument and fringe benefits are critical clairvoyant of efficiency and productivity (Sutton and Bergerson, 2001; Okpabi, 2003; Peretomode, 2001; Adeyemi, 1991 and Olakunri, 2001). Forms of rewards and incentives applied in tertiary institutions to fascinate staff towards maximum input. To this end, fringe benefits such as research grants, transport allowances, examination supervision/teaching practice allowances, journal hazards, meal subsidies and rent allowances could be a motivational factor that can turn around the effectiveness of lecturers in tertiary institutions in the country. 


\section{Recommendation}

The following recommendations are made based on the research findings:

1. Emoluments and other fringe benefits of lecturers should be paid as and when due

2. Incentives such as academic earn allowances should be regular, this would help spur lecturers in their commitment to duties

3. Lecturers deserve their wages/salaries, so managements should endeavor to pay lecturers wages equitable with their counterparts in the world, this would motive them to work.

\section{References}

Adeyemi, M. O. (1991). Remuneration packages in financial institutions, policy, issues, trend and objectives. Journal of personal management of Nigeria, 5(1), 6-8.

Casio, W. (1992). Managing human resources. New York: McGraw-Hill.

Ejiogu, A. M. (1980). Theories of job satisfaction and job performance. An overview and critiques. Lagos: Jaja Press.

Fabiyi, A. I. (2000). Lecturers job satisfaction and progremme in Nigeria college of education. In E. O. Fagbamiye and D. O. Durosaro (Eds.), Education and Productivity in Nigeria, (pp. 123-154). Ilorin: NAEAP.

Heller, R. and Hindle, T. (1998). Essential managers' manual. London: Dorling $\quad$ Kinderesley.

Lillydahl, J. H. and Sungell, L. D. (1993). Job satisfaction, salaries and unions: the determination of university faculty compensation. Economic of education review, 12(3),234-243.

Ndagi, A. Y. (2006). The problem of retention in primary school teacher in Bida, Agale North Western State. Unpublished B.Ed. Project, faculty of education, Ahmedu Bello university Zaria, Nigeria.

Okpabi, V. E. (1990). Factore that influence teachers' effectiveness in secondary schools in Geokona Tai Eleme Local Government Area of River State. Unpublished M.Ed. thesis, faculty of education, university of Calabar, Nigeria.

Oswald, E. A. (2006). Compensation system attitude to work and job effectiveness of secondary school teachers in Cross River State. Unpublished Ph.D. thesis, faculty of education, university of Calabar, Nigeria.

Peretomode, V. F. (2001). Educational administration: Applied concepts and theoretical perspectives. Ikeja: Jaja Educational Research and Publisher.

Udey, F. U. (2002). Rewards system and teachers' attitude to work in northern senatorial Zone of Cross River State. Unpublished M.Ed. thesis, faculty of education, university of Calabar, Nigeria. 